\title{
EVALUATION OF QTC INTERVAL IN CIRRHOSIS PATIENTS WITH VARICEAL HEMORRHAGE
}

\author{
VARIS KANAMASI OLAN SIROZ HASTALARINDA OTC INTERVALININ \\ DEĞERLENDIRILMESI
}

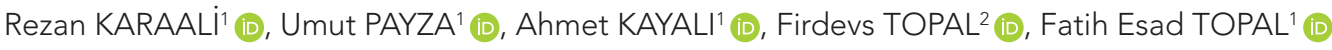 \\ 'İzmir Katip Çelebi Üniversitesi, Atatürk Eğitim Araştırma Hastanesi, Acil Tıp Anabilim Dalı, İzmir, Türkiye \\ 2̇zmir Katip Çelebi Üniversitesi, Atatürk Eğitim Araştırma Hastanesi, Gastroenteroloji Kliniği, İzmir, Türkiye
}

ORCID IDs of the authors: R.K. 0000-0003-1831-2566; U.P. 0000-0002-5297-1066; A.K. 0000-0003-2557-0600;

F.T. 0000-0001-8270-8309; F.E.T. 0000-0002-9941-4224

Cite this article as: Karaali R, Payza U, Kayali A, Topal F, Topal FE. Evaluation of QTc interval in cirrhosis patients with variceal hemorrhage. J Ist Faculty Med 2021;84(2):181-5. doi: 10.26650/IUITFD.2020.0055

\section{ABSTRACT}

Objective: In this study, we investigated the effect of the QTc interval in cirrhosis patients on mortality and morbidity in esophageal variceal hemorrhages.

Material and Method: It was retrospectively scanned in a single-centred design. The QTC intervals before and during the bleeding were calculated. The demographic characteristics and mortality status were recorded.

Results: Bleeding was detected in 117 of the 156 patients. A total of $83 \%$ of these were male, and $17 \%$ were female. The QTc interval in these patients measured at the time of bleeding was longer than that measured before bleeding $(p<0.001)$. The QTc interval of the patients who died due to bleeding was found to be 509.9 ms. It was calculated for males as 520.6 ms, and 487.4 ms for females. In the ROC analysis that was conducted for the QTc in terms of mortality, the sensitivity was $82.4 \%$ and specificity was $79.7 \%$ for $464.0 \mathrm{~ms}$ in males (AUC:0.785; 95\% Cl 0.724-0.825). The sensitivity was $77.8 \%$ and the specificity was $90.0 \%$ for QTc's 454.0 ms cutoff value for females (AUC:856; 95\% Cl 0.812-0.862).

Conclusion: The QTC interval is prolonged in the case of esophageal variceal hemorrhage in patients diagnosed with cirrhosis. A prolonged QTC interval is associated with mortality and morbidity of patients.

Keywords: Emergency department, cirrhosis, QTc interval, variceal hemorrhage

\section{ÖZET}

Amaç: Bu çalışmada QTc intervalinin siroz hastalarında meydana gelen özofagus varis kanamasının mortalite ve morbidite üzerindeki etkisi araştırıldı.

Gereç ve Yöntem: Çalışma, retrospektif, tek merkezli yapıldı. Hastaların kanama öncesi ve kanama anındaki QTc intervalleri hesaplandı. Hastaların demografik özellikleri ve mortalite durumları kaydedildi.

Bulgular: Yüz elli altı hastanın 117'sinde kanama saptandı. Bunların \%83'ü erkek, \%17'si kadındı. Kanama anında ölçülen QTc intervali kanama öncesi ölçülenden uzundu $(p<0,001)$. Kanama nedeniyle ölen hastaların QTc süresi 509,9 ms olarak bulundu. Erkekler için hesaplanan QTc değeri 520,6 ms ve kadınlar için hesaplanan 487,4 ms idi. Mortalite açısından QTc için yapılan ROC analizinde, erkeklerde $464,0 \mathrm{~ms}$ için sensitivite $\% 82,4$ ve spesivite $\% 79,7$ olarak bulundu (AUC:0,785; 95\% Cl 0.724-0,825). Kadınlarda QTc'nin 454,0 ms, cutoff değeri için sensitivite \%77,8 ve spesivite \%90,0 olarak bulundu (AUC:856; 95\% Cl 0.812-0,862).

Sonuç: Siroz tanısı olan hastalarda özofagus varis kanaması durumunda QTc intervali uzamaktadır. Uzamış QTc intervali hastaların mortalite ve morbiditesi ile ilişkilidir.

Anahtar Kelimeler: Acil servis, siroz, QTc intervali, varis kanaması

Corresponding author/iletişim kurulacak yazar: rezantahtaci@hotmail.com

Submitted/Başvuru: 10.05.2020 • Revision Requested/Revizyon Talebi: 07.07.2020 •

Last Revision Received/Son Revizyon: 14.10.2020 • Accepted/Kabul: 05.11.2020 • Published Online/Online Yayın: 01.04 .2021 


\section{INTRODUCTION}

Cirrhosis is among the most common diseases in terms of hospitalisation and mortality rates worldwide because of the damage to liver cells caused by infections, alcohol, drugs, or hereditary enzyme deficiency (1). Patients are at risk of mortality because of the damage caused by cirrhosis in the liver, as well as its effects on the heart. Cirrhosis causes cardiomyopathy (CCM), which causes weak contraction and relaxation of the heart. CCM has significant electrophysiological changes, which can be detected with Electrocardiogram (ECG) $(1,2)$. Depolarisation and repolarisation of the ventricles are delayed because of the slow-down of the transmission in the myocardia, which, in return, causes the prolongation of QT interval in the ECG (3). The prolongation in the QT interval causes increased heart rate, decreased myocardial contraction strength, and diastolic dysfunction. The deterioration in the transmission in the ventricle increases the risk of ventricular arrhythmia, especially polymorphic ventricular tachycardia, which can result in ventricular fibrillation and sudden death $(2,4,5)$. It was shown in previous studies that the prolonged QT interval because of cirrhosis was directly proportional to the severity of cirrhosis, and there is healing after liver transplantation. For this reason, it is used as the marker of the severity of the disease (1).

Another fatal condition in cirrhotic patients is Gastrointestinal Bleeding (GIB), which is caused mostly by the rupture of the gastro-esophageal varicose veins $(6,7)$. No matter based on rupture of the gastro-esophageal varicose veins, the 6-week mortality rate of GIB is $0-30 \%$ (6). The anemia, hypotension and tachycardia that appear because of the bleeding also cause myocardial ischemia. For this reason, the clinical condition is even more severe in patients with CCM and prolonged QT (8). However, although acute GIB prolongs the QT in patients with cirrhosis without underlying cardiac disease, there was no such effect in those without cirrhosis $(6,8)$.

In this study, the effect of the esophageal variceal hemorrhage on the QT interval was examined in patients diagnosed with cirrhosis. The effects of the changes in the QT interval on mortality and morbidity of the disease were also investigated in the presence of active bleeding.

\section{MATERIAL AND METHOD}

\section{Study setting and population}

The study was conducted in the Emergency Department of our hospital in a retrospective and single-centre design between January 2009 and December 2019. Our hospital has the largest gastroenterology unit in the area with 50 beds, receiving an average of 65,000 admissions on an annual basis. In addition, the third-degree emergency department is the one that receives the highest emergency service admissions.
Patients diagnosed with cirrhosis and referred to the emergency department with acute gastrointestinal bleeding were scanned in the database of our hospital according to the ICD-10 Diagnostic Code (K 74). The patients with traumas, pregnant women, malignancies, cardiac diseases like heart failure and arrhythmia were excluded from the study. The patients who were over the age of 18, whose QTc intervals were normal in their ECGs that were evaluated in the database, and who had sufficient data available in their files, were included in the study.

\section{Data collection}

The demographic characteristics of the patients like age and gender were recorded from the hospital database. Comorbid disease status was also recorded. The cirrhosis severity was evaluated and recorded according to Child-Pugh Scoring $(9,10)$. All the Emergency Department admissions of the patients with/without bleeding were recorded according to their protocol numbers. According to the endoscopy reports performed after each admission, bleeding because of the varicose vein was recorded. The ECGs that were taken during routine checkups no later than 30 days before the admissions due to bleeding were accepted as basic ECG of the patients. In admissions to the Emergency Department with GIB, the ECGs taken before endoscopy were considered as bleeding period ECGs. The ECGs that were taken at the time of hospitalisation for follow-ups of the patients with bleeding in endoscopy were recorded from the archive data as post-bleeding ECGs.

The QT interval was calculated with extremity derivation DIl by starting from the ORS complex according to the descending end of the T wave isoelectric line (3). The corrected $\mathrm{QT}$ (OTc) value was calculated by using the Bazzet Formula. The Bazzet Formula is called as QT interval in milliseconds divided into the square root of the RR interval seconds by using the RR interval between the previous and measured complex (11). The American Heart Association (AHA) guide, which issued for extended an QTc period, was taken as the basis. In this Guideline, if the QTc is $>460 \mathrm{~ms}$ in females, and $>450 \mathrm{~ms}$ in males, it is considered that the QTc is prolonged (12).

The 30-day mortality of the patients after/as of the admission with bleeding was recorded.

\section{Statistical method}

The statistical analysis of the data was carried out with the IBM Statistics version 24.00 program. The continuous distribution of the data was examined with the Kolmogorov Smirnov Test. The Mann Whitney U Statistical Analysis was used in the comparison of the continuous data between the two groups. A p value $<0.05$ was considered to be statistically significant. 


\section{Ethical considerations}

Permission for the study was obtained from Izmir Katip Çelebi University, Ataturk Education and Research Hospital Ethics Committee (21.01.2020 - 2019-GOKAE-1360). The entire study process was conducted in line with the Helsinki Declaration.

\section{RESULTS}

A total of 156 patients were included in line with the inclusion criteria in our study. All cases had a total of 326 admissions in the Emergency Service because of Gastrointestinal Bleeding (GIB). A total of 118 (76\%) of the patients were male, and $38(24 \%)$ were female. The mean age of males was $61.07 \pm 12.47$, and the mean age of females was $57.11 \pm 10.81$. The mean age of the patients was correlated with their gender. No statistically significant differences were detected between the mean age of males and females who were examined ( $p>0.05)$.

According to the endoscopy reports in the database, 117 $(76 \%)$ of the patients had bleeding. Esophageal variceal hemorrhage was detected in 104 (83\%) of the male patients, and in $13(17 \%)$ of the female patients. There was a statistically significant difference between the GIB rates of the male and female cases ( $p>0.05)$. A total of $18 \%$ of the patients had additional comorbidities; and $29.87 \%$ were Child-A, $35.06 \%$ Child-B, and $35.07 \%$ were Child-C cirrhosis.

Mortality due to GIB was detected in 56 (35.9\%) of the patients who were included in the study. A total of 49 (31.4\%) of the male patients died because of esophageal variceal hemorrhage.

The mean QTc calculated from ECGs before the bleeding of all patients was found to be $395.5 \mathrm{~ms}$. The QTc value of the male patients was calculated as $398 \mathrm{~ms}$, and that of the female patients was $387.1 \mathrm{~ms}$. No statistical difference was detected in the calculated QTc values of male and female cases.

The mean QTc of the patients who had bleeding was determined to be $473.4 \mathrm{~ms}$ in endoscopy. The QTc values of the patients with bleeding were found to be statistically and significantly higher than the QTc values before bleeding ( $p<0.001)$. The QTc of male patients with bleeding was $478.7 \mathrm{~ms}$, and $455.1 \mathrm{~ms}$ in female patients. A statistical difference was detected in the QTc values calculated from male and female patients who had bleeding $(p=0.023)$.

The QTC intervals of the patients who died because of GIB was found to be $509.9 \mathrm{~ms}$. The QTc value calculated for males was $520.6 \mathrm{~ms}$, and $487.4 \mathrm{~ms}$ for females. When the mean values of male patients who died because of bleeding were evaluated, the surviving cases had statis- tically significant differences in terms of the QTc values. When the mean values of female patients who died because bleeding was evaluated, the surviving cases had statistically significant differences in terms of the QTc values (Table 1).

Table 1: QTc values in case of bleeding and death by gender

\begin{tabular}{lcccc}
\hline & Male & Female & Total & p \\
\hline $\begin{array}{l}\text { Before } \\
\text { bleeding }\end{array}$ & $398.0 \mathrm{~ms}$ & $387.1 \mathrm{~ms}$ & $395.5 \mathrm{~ms}$ & 0.309 \\
$\begin{array}{l}\text { During } \\
\text { bleeding }\end{array}$ & $478.7 \mathrm{~ms}$ & $455.1 \mathrm{~ms}$ & $473.4 \mathrm{~ms}$ & $\mathbf{0 . 0 2 3}$ \\
$\begin{array}{l}\text { Death due } \\
\text { to bleeding }\end{array}$ & $520.6 \mathrm{~ms}$ & $487.4 \mathrm{~ms}$ & $509.9 \mathrm{~ms}$ & $\mathbf{0 . 0 4 1}$ \\
\hline
\end{tabular}

The QTc cut-off value was calculated in patients who died because of bleeding. This value was $464.0 \mathrm{~ms}$ in males. The sensitivity of QTC cutoff value was $82.4 \%$, and the specificity was $79.7 \%$ (AUC:0.785; 95\% Cl 0.724-0.825). This value was $454.0 \mathrm{~ms}$ in females. The sensitivity of QTc cutoff value was $77.8 \%$, and specificity was $90.0 \%$ (AUC:856; 95\% Cl 0.812-0.862) (Graphic 1).

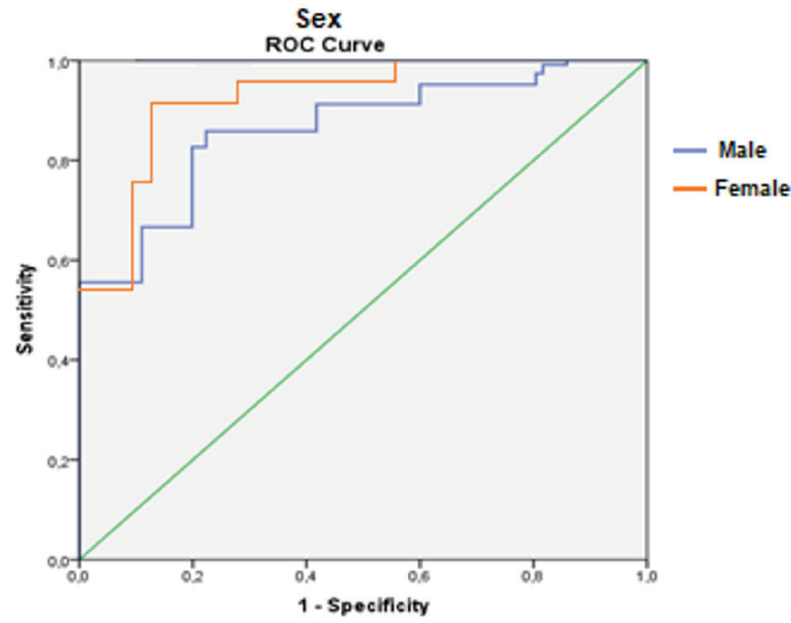

Graphic 1: Receiver Operating Characteristic (ROC) curve of QTc interval in predicting mortality

When the QTC values according to bleeding status and mortality were evaluated, there was a statistically significant difference between the QTC values in males based on bleeding and mortality ( $p_{\text {bleeding }}=0.001$ and $p_{\text {mortality }}<0.001$, respectively). A statistically significant difference was detected in females based on their bleeding and mortality status ( $p_{\text {bleeding }}=0.016$ and $p_{\text {mortality }}<0.001$, respectively). In this respect, in the case of bleeding in both genders, the OTC intervals were prolonged and the QTc was longer in mortal cases. 


\section{DISCUSSION}

Cirrhosis progresses with the destruction of the liver and heart cells. It has complications like portal hypertension, acid, variceal hemorrhage, encephalopathy, hepatorenal-hepatopulmonary syndrome, and hepatocellular carcinoma. Cirrhotic Cardiomyopathy (CCM), in which the systolic and diastolic function deteriorate in the heart, is also observed $(5,11)$. The CCM was first described by Kowalski and Abelmann as increased cardiac output, decreased stroke volume, normal blood pressure, and decreased systemic resistance (14). In the following years, the diagnostic criteria of the cirrhotic CCM were defined by Figueiredo, and the QTc interval was among the supportive criteria (15).

Bokardiva et al. reported that $46 \%$ of the 586 cirrhosis patients developed CCM in their study conducted on cirrhotic CCM prevalence. The QTc interval was prolonged in $75.8 \%$ of patients diagnosed with CCM. The risk factors like diabetes, alcohol, hypertension, hypothyroidism, which prolong the duration of QTc, were excluded in this study (2). In his study conducted on Hepatitis C (HCV) patients, Abbas et al. found that QTc was longer than normal in $24.5 \%$ of these patients. They also compared patients who had cirrhosis with patients who did not have cirrhosis, and reported that $57.9 \%$ of HCV cirrhosis patients had prolonged QTc intervals (1). Mashod Ali et al. conducted a study and evaluated the relation between the severity of cirrhosis and the OTc interval. They evaluated the severity of cirrhosis according to Child-TurcotPugh Classification, and reported that the OTc interval was prolonged in all stages of cirrhosis. In the same study, they emphasised that $72 \%$ of Class C patients had OTC intervals longer than expected. It was shown that as the severity of cirrhosis increases, the effects on the heart will also increase, and prolonged OTc intervals in cirrhosis indicated the severity of cirrhosis and cardiac exposure (5). Zambrumi et al. reported that the final stage of the effects of cirrhosis on the heart was the prolongation of the QTc intervals. They reported that QTc prolongation indicated high damage to the liver and heart cells (17).

In the present study, the subgroup of patients diagnosed with cirrhosis with pathological and radiological findings and those who had endoscopically-proven esophagus varicose was examined. The QTc interval was detected to be at normal limits in ECG carried out before bleeding of these patients who admitted with GIB complaints. It was also calculated that QTc was prolonged before bleeding in all cases that had bleeding. However, it was found that the male patients with variceal hemorrhage in esophagus had significantly longer QTc interval compared to female patients. We believe that the developing cardiomyopathy and portal hypertension cause a cardiac effect. In addition, we see the ischemia caused by anemia devel- oping due to bleeding and circulatory disorder on the heart as a prolongation of QTc interval in ECG. However, we also believe that this higher effect in male patients might have occurred because of a higher prevalence of cardiac events and lower cardiac reserves in males. Parallel to our study, Peter et al. conducted a study on cirrhosis patients and showed that the QTc interval was prolonged in cirrhosis patients, and that QTc was longer when variceal hemorrhage developed in these patients (QTc: 468). They also noted that the difference between these two values was an independent risk factor in predicting Hepatorenal syndrome. In this respect, they argued that QTC was a good tool in predicting the severity of cirrhosis and the risk of bleeding (13).

In Zhao et al.'s study, they classified cirrhosis patients according to QTC intervals. Similar to the results of the present study, they reported that there was a significant relation between GIB and QTc prolongation. They also argued that the probability of GIB would be high in cirrhosis patients with a long OTC interval (18). In Trevisani et al.'s study, patients who applied for non-cirrhosis due to upper GIB were evaluated. They compared the ECGs of patients with GIB before and after bleeding, and found that the QTc values were prolonged at the time of bleeding, and only returned to the baseline after 6 months. They also argued that the QTc prolongation detected in patients was associated with GIB (8). In our study, it was found that the normal QTc interval before bleeding was prolonged when bleeding occurred. Our findings support the findings of previous studies.

Another result of our study was that the QTc prolongation after bleeding was associated with mortality. There was a strong and linear relation between QTc intervals and mortality in both genders. The onset of QTc prolongation in patients with cirrhosis is also increased in direct proportion to mortality. As QTc is prolonged, mortality increases. Biselli et al. evaluated the effect of MELD-Na score and OTc interval on 6-week mortality. They included patients who lived for at least one day after bleeding in their study, and recommended a new scoring that included the MELD-Na score and QTc. He argued that this new scoring was more specific and sensitive in predicting mortality (6). Parallel to the findings obtained in our study, Biselli et al. revealed the strong relation of QTc with mortality.

\section{CONCLUSION}

QTc is an easy-to-calculate, non-invasive and reliable method for these patients. We believe that this prolongation in QTc interval in patients especially with high-volume bleeding like esophagus variceal hemorrhage will be a guide to indicate mortality and morbidity. For this reason, we believe that the changes in the QTc interval should be closely monitored in patients diagnosed with cirrhosis. 


\section{Limitations}

Although the study was conducted in a hospital with the largest gastroenterology unit in the region, it was done as a single-centre. In addition, it is necessary to support the results with further studies to be conducted with wider patient groups.

Ethics Committee Approval: This study was approved by the Izmir Katip Çelebi University, Ataturk Education and Research Hospital Ethics Committee (Date:21.01.2020-2019, No:GOKAE-1360).

Peer Review: Externally peer-reviewed.

Author Contributions: Conception/Design of Study- R.K.; Data Acquisition- R.K., F.T., A.K., H.M.B.; Data Analysis/InterpretationR.K., U.P., F.E.T., A.K.; Drafting Manuscript-R.K., A.K.; Critical Revision of Manuscript- U.P., F.T., F.E.T.; Final Approval and Accountability- R.K. U.P., A.K., F.T., F.E.T.

Conflict of Interest: Authors declared no conflict of interest.

Financial Disclosure: Authors declared no financial support.

Etik Komite Onayı: Bu çalışma için etik komite onayı İzmir Katip Çelebi Üniversitesi, Atatürk Eğitim ve Araştırma Hastanesi Etik Kurulu'ndan alınmıştır (Tarih:21.01.2020-2019, Sayı:GOKAE-1360).

Hakem Değerlendirmesi: Dış bağımsız.

Yazar Katkıları: Çalışma Konsepti/Tasarım-R.K.; Veri ToplamaR.K., F.T., A.K.; Veri Analizi/Yorumlama- R.K., U.P., F.E.T., A.K.; Yazı Taslağı- R.K., A.K.; İçeriğin Eleştirel İncelemesi- U.P., F.T., F.E.T.; Son Onay ve Sorumluluk- R.K. U.P., A.K., F.T., F.E.T.

Çıkar Çatışması: Yazarlar çıkar çatışması beyan etmemişlerdir.

Finansal Destek: Yazarlar finansal destek beyan etmemişlerdir.

\section{REFERENCES}

1. Abbas A, Khan F, Rehman S, Ahsan O, Afzal A. Comparison of QTC interval prolongation in cirrhotic and non-cirrhotic chronic hepatitis c patients. Annals of Pims 2018;14(2):135-8.

2. Bokarvadia R, Jain M, Kedarisetty C, Varghese J, Venkatarama J. prevalence and clinical presentation of cirrhotic cardiomyopathy: a single centre experience from Southern India. Indian Journal Of Gastroenterology 2019; 38(2):150-7. [CrossRef]

3. Moss AJ. Measurement of the QT interval and the risk associated with QTC interval prolongation: A Review. Am J Cardid 1993;72:23-5. [CrossRef]

4. Elming H, Brendorp B, Køber L, Sahebzadah N, TorpPetersen C. QTc interval in the assessment of cardiac risk. Cardiac Electrophysiology Review 2002;6:289-94. [CrossRef]

5. Ali M, Shahzad A, Adil IK, Alam S, Noor H, Imran A, Ganito N. Frequency of Corrected QT Interval in Patients With Cirrhosis. Journal of Rawalpindi Medical College (JRMC) 2016;20(2):79-81.
6. Biselli M, Gramenzi A, Lenzi B, Dall'Agata M, Pierro ML, Perricone $\mathrm{G}$, et al. Development and validation of a scoring system that includes corrected QT interval for risk analysis of patients with cirrhosis and gastrointestinal bleeding. Clinical Gastroenterology and Hepatology 2019;17:138897. [CrossRef]

7. Bambha K, Kim WR, Pedersen R, Bida JP, Kremers WK, Kamath PS. predictors of early re-bleeding and mortality after acute variceal haemorrhage in patients with cirrhosis. Gut 2008;57:814-20. [CrossRef]

8. Trevisani F, Di Micoli A, Zambruni A, Biselli M, Santi V, Erroi $V$, et al. QT interval prolongation by acute gastrointestinal bleeding in patients with cirrhosis. Liver Int 2012;32(10):15105. [CrossRef]

9. Child CG, Turcotte JG. Surgery and Portal Hypertension. In: Child, C.G., Ed., The Liver and Portal Hypertension, Saunders, Philadelphia, 1964.P.50-64.

10. Pugh RN, Murray-Lyon IM, Dawson JL, Pietroni MC, Williams R. Transection of the oesophagus for bleeding oesophageal varices. Br J Surg 1973;60(8):646-9. [CrossRef]

11. Bazett HC. An analysis of the time relations of electrocardiogram. Heart 1920;7:53-70. [CrossRef]

12. Rautaharju PM, Surawicz B, Gettes LS, Bailey JJ, Childers R, Deal BJ, et al. AHA/ACCF/HRS recommendations for the standardization and interpretation of the electrocardiogram: part IV: the ST segment, T and U waves, andthe QT interval: a scientific statement from the American Heart Association Electrocardiography and Arrhythmias Committee, Council on Clinical Cardiology; the American College of Cardiology Foundation and the Heart Rhythm Society. Endorsed by the International Society for Computerized Electrocardiology. J Am Coll Cardio 2009;53(11):982-91. [CrossRef]

13. Peter G, George PC, Villyoth MP, Sivaraman S, Hamza RE, Srijith SBK, et al. QT interval prolongation: A risk factor for development of hepatorenal syndrome in cirrhotic patients with acute variceal bleeding. Tropical Gastroenterology 2014;35(3):157-63. [CrossRef]

14. Kowalskı HJ, Abelmann WH. The cardiac output at rest in Laennec's cirrhosis. J Clin Invest 1953;32(10):1025-33. [CrossRef]

15. Figueiredo A, Bermejo FR, Perdigoto R, Marcelino P. The end-organ impairment in liver cirrhosis: appointments for critical care. Crit Care Res Pract 2012;2012:539412. [CrossRef]

16. Pudila R, Peloucha R, Prausa R, Vasatovab M, Hulekc P. Heart failure in patients with liver cirrhosis. Cor et Vasa 2013;55(4):391-6. [CrossRef]

17. Zambruni A, Trevisani F, Caraceni P, Bernardi M. Cardiac electrophysiological abnormalities in patients with cirrhosis. J Hepatol 2006;44(5):994-1002. [CrossRef]

18. Zhao J, Qi X, Hou F, Ning Z, Zhang X. Deng H, et al. Prevalence, risk factors and in-hospital outcomes of qtc interval prolongation in liver cirrhosis. Am J Med Sci 2016;352(3):285-95. [CrossRef] 